\title{
Sexing-Up the Subject
}

\section{An Elaboration of Feminist Critique as Intervention}

\author{
Cathrine Egeland
}

UNIVERSITY OF BERGEN

\begin{abstract}
The decisive epistemological and methodological moment of feminist analysis and critique is the moment of intervention. An intervention does not require a standpoint; instead, it displaces the locus of critique from the standpoint to the effects or consequences of critique. Intervention requires no new information or hitherto concealed facts about the object being interfered with. The critical effects of an intervention are the results of what is called a 'sexing-up' strategy. Different epistemological and methodological aspects of this strategy are discussed and a connection established between feminist interventions in science and politics, and the strategy of sexing-up.
\end{abstract}

KEY WORDS critique $\bullet$ feminism $\bullet$ intervention $\bullet$ phallogocentrism $\bullet$ science $\bullet$ sexing-up translation

In this article, I approach and elaborate the notion of feminist critique as intervention. I do this by presenting some epistemological and methodological considerations revolving around what I would like to call the 'strategy of sexing-up'. This strategy is far from my invention since it is a common phenomenon not only in political life, but also in scientific activity as well as in human and non-human communication. My contribution is to establish a connection between critical interventions in science and politics and the strategy of sexing-up. Before I probe into the rather disparaging expression 'sexing-up', I give an account of feminist critique as intervention. I then discuss some epistemological and methodological challenges and implications of the strategy of sexing-up, as an essential aspect of feminist intervention by involving some arguments and insights from the works of Bruno Latour, Michel Foucault and Luce Irigaray. Finally, I show how a sexing-up strategy might be applied to empirical research by addressing the question of gender equality in academia. ${ }^{1}$

European Journal of Women's Studies Copyright (C) 2005 SAGE Publications (London, Thousand Oaks and New Delhi), 1350-5068 Vol. 12(3): 267-280; DOI: $10.1177 / 1350506805054268$ 


\section{THIS IS NOT AN EXIT}

Feminist theory is marked by the challenge that there is no simple or correct way to situate oneself outside phallogocentrism 'that would result from the simple fact of being a woman' (Irigaray, 1985b: 162). This challenge has left those feminists working in the fields of epistemology and methodology in the uneasy, but promising, situation of having to develop concepts and tools of analysis and critique that do not presuppose a standpoint of resistance outside phallogocentrism. A standpoint given by the categories of 'woman' or 'women', or by the notion of tacit female knowledge, or by a final moment of truth where feminist politics and knowledge are somehow fused in a higher unity, and so on. Over the years, this situation has drawn feminist researchers' attention to the risk they themselves run of reproducing hegemonic gender discourses, employing concepts and practices recognized as intelligible and legitimate by and within the very same social, cultural and symbolic order that produces and reproduces invisibility, exclusion and inequality: the objects of feminist analysis and critique. On the other hand, this situation has also caused some uneasiness among feminist researchers: How can feminist analysis and critique unfold as a feminist endeavour without a standpoint or locus of critique given by the unified or unifying category of 'woman', or a narrative of oppression and emancipation of 'women'? How is feminist critique possible if it is impossible to situate the locus of critique outside phallogocentrism?

One way to approach this problem is to rethink the subject of feminist critical thinking. In Metamorphoses, Rosi Braidotti (2002) is reclaiming sexual difference as a decisive part of feminist theory by rethinking materiality and embodied subjectivity, in terms of transformation and change. As she puts it in the prologue, we are living in:

Times of fast-moving changes which do not wipe out the brutality of power relations, but in many ways intensify them and bring them to the point of implosion. Living in such times of fast change may be exhilarating, yet the task of representing these changes to ourselves and engaging productively with the contradictions, paradoxes and injustices they engender is a perennial challenge. (Braidotti, 2002: 1)

Braidotti's answer to this challenge is to replace the question of being with the question of becoming; a feminist analysis and critique of 'our' times cannot take the stable categories of 'woman' and 'women' as a point of departure. Rather, it must rethink subjectivity, by 're-inventing the very image of the subject as an entity fully immersed in relations of power, knowledge and desire' (Braidotti, 2002: 7). This is a logical move to make in an attempt at deconstructing the essentialist tendencies in feminist theory; by introducing the question of becoming, as part of a reinvention 
of subjectivity feminist critique without reference to a stable standpoint of critique.

Another way to make sense of feminist critique without presupposing a standpoint of critique - given by the unified or unifying category of 'woman' - is to situate the decisive moment of feminist critique in the consequences of the critique; consequences both of 30 years of second-wave feminism for contemporary feminist thinking, as well as consequences of contemporary feminist thinking for the assessment of the multiple histories of feminism and for the future of feminist thinking (Kavka, 2001: xii). This emphasis on the consequences rather than the standpoint of feminist critique - given by the category of women - not only seems to be able to heal the wounds on the feminist body left on the theoretical battlefields of the 1990s. ${ }^{2}$ It also opens up the possibilities of a critical revision of critique, since feminism understood as critique tends to turn on the negative relation between the locus - reduced to the foundations - and the object of critique rather than the consequences of the critical endeavour. I have elsewhere (Egeland, 2003, 2004) discussed the possibility of understanding feminist critique as intervention. Arild Utaker (1984) explains critique as intervention as a form of critique interfering with the object of critique. To intervene or interfere is to describe the object of critique neither from the 'outside' of the object, nor from a perspective that is limited by the criteria defining the object. Critique as intervention can thus be conceived of as a strategy aimed at describing, redescribing, combining and recombining elements of knowledge that may have critical effects. Michel Foucault, for instance, exercises critique as intervention by linking practices of power with practices of knowledge - instead of separating them by describing them in opposition to one another (Schaanning, 2000). An intervention does not require a standpoint, instead, it displaces the locus of critique from the standpoint to the effects or consequences of critique. Intervention is thus a positive, non-veracious project.

Another important aspect of the notion of intervention is that it does not require new information or hitherto concealed facts about the object being interfered with. On the contrary, the critical effects of an intervention are the results of descriptions, redescriptions, combinations and recombinations of the criteria already defining the object in question. Understood in this way an intervention involves crucial elements of what can be called a sexing-up-strategy.

To 'sex up' something is to exaggerate, hype up or highlight it. In Norwegian, the corresponding expression is sprite opp - i.e. to infuse an object with alcohol or spirits to make it appear more interesting than it perhaps otherwise would have been. To 'sex up' is thus not to lie about an object or a situation, but to infuse them with elements that make them noticeable. These elements do not have to originate from another context than the context of the object of the sexing-up strategy, but they must 
contribute to a process where the object is made more noticeable, attractive, interesting or worth some exploration. To sex up an object is necessarily to intervene in and interfere with the criteria defining the object in order to attain specific effects. This also means that the criteria defining the object are exposed. To employ a sexing-up strategy, in an intervention, is to interfere - not out of innocence or ignorance, but out of resultoriented considerations. To sex up a subject is to deny claims of truth. The effect of an intervention involving sexing-up strategies does not refer to a standpoint of truth guaranteeing the legitimacy of the intervention.

Few, if any would dispute that politics and political arguments rest heavily on interventions involving sexing-up strategies. Or else nothing would 'happen'; no decisions would be made, no action would take place. A significant - and successful - sexing-up case from the realms of politics is the British government's sexing-up of the documents concerning Iraq's so-called 'weapons of mass destruction' in the autumn of 2002.

\section{SEXING-UP - A CASE STORY}

During the build-up to the US-orchestrated invasion of Iraq in March 2003, the British government in September 2002 produced a long-awaited dossier of evidence about Iraq's weapons of mass destruction. Among its claims - as highlighted in Prime Minister Tony Blair's foreword - was that '[Iraq's President Saddam Hussein's] military planning allows for some of the weapons of mass destruction to be ready within 45 minutes of an order to use them'. In May 2003, an anonymous official said to have been involved in drawing up the dossier told BBC Radio 4's Today programme defence correspondent Andrew Gilligan that the document was 'sexed up' at the behest of Downing Street against the wishes of the intelligence services.

Since the British government's justification for joining the invasion of Iraq was the threat posed by Saddam Hussein's weapons of mass destruction, this accusation was a serious and undermining blow to the arguments that had legitimated the UK's active part in the coalition forces. The accusation was thus vigorously denied while the anonymous official was eventually revealed as Dr David Kelly, who later committed suicide. The British government's reputation had already worn pretty thin, but Lord Hutton's investigation - following in the wake of Dr Kelly's suicide - tried to pour calming oil onto troubled water, by concluding that the dossier could be said to have been 'sexed up', if this expression implied that it was drafted to make the case against Saddam Hussein as strong as intelligence permitted. In the context of the accusations made against the government, however, 'sexed up' was understood to mean that the dossier had been embellished with items of intelligence which the 
government itself knew or believed to be unreliable, or even downright false. And, the Hutton report concluded, this allegation was unfounded. ${ }^{3}$ The British government was released of the accusations made against it, and the continual justification of the war against terrorism could go on as planned.

Now, how is this excerpt from the neo-imperialist discourse of 'war against terrorism' interesting for an elaboration of feminist intervention? It is interesting because it illustrates how an intervention by means of a sexing-up strategy interferes with and changes the object in question, thus clearing the way for a specific conclusion and a specific action to take place. The sexed-up arguments in the case described were turned into questions of style; they were only drafted to make the case as strong as the already approved knowledge permitted. After the British government was cleared of the accusation of sexing-up information in an illegitimate way - i.e. having embellished the information with items known or believed to be unreliable or downright false - the sexed-up arguments continued to function in the building up of the atmosphere calling for action against Iraq. All the British government had to do was to disassociate itself from a specific illegitimate and invalid means irrespective of the action in question. Confronted with accusations of 'sexing-up' the dossiers of evidence about Iraq's weapons of mass destruction, they only had to deny that the dossiers rested on an illegitimate, invalid and thus tottering foundation - i.e. on false information about the military situation in Iraq. Warfare was never the problem, only the nature of the arguments that made it necessary. And as long as the British government could argue that the sexing-up strategy was employed not in order to produce a false picture of the situation but in order to make the case against the enemy as strong as possible, everything was in perfect order. The intervention was successful.

Now, this is politics. But why should it not be part of science and of analysis and critique? Why should interventions involving sexing-up arguments be dismissed? Is it because they are sexy or attractive in a disturbing and unpleasant way? As I have mentioned earlier, sexed-up arguments are not the result of powerless, innocence or ignorance; they are the result of result-oriented considerations. Like prostitutes faking it for a living, sexed-up arguments are being used and abused for different purposes, but seldom in the broad daylight of science. They are best avoided. Or perhaps not? In what follows, I try to show that even if sexing-up might be interpreted as a monstrous and illegal strategy, leading to a deadly end for some parties - as in the case of the sexed-up dossier of evidence about Iraq's weapons of mass destruction - sexing-up might not only be a promising methodological tool in feminist analysis and critique; interventions involving sexing-up strategies are already part of science. 


\section{TRANSLATING 'SEXING-UP’ INTO ‘TRANSLATION’}

Post-positivist and feminist theories and studies of science and scientific activity have brought to light many of the cultural, ideological and discursive struggles that permeate or even precondition science and scientific activity beneath the surface of the ethos of science - an ethos described by Robert Merton as the interrelated norms of universalism, 'communism', disinterestedness and organized scepticism (see Merton, 1996). Bruno Latour's (1987) Science in Action, for example, describes the way 'sexingup' subjects - or 'translation' as Latour calls it - is a necessary and unavoidable strategy in scientific activity. Scientists cannot avoid 'sexing-up' subjects because their activity is nothing without the support of an extrascientific context; scientists are wilful actors that constantly have to attend to and unfold an activity in a dependence to their surroundings.

This rather trivial observation represents a severe blow to any confusion of scientific activity with the ethos of science. Instead of being the results of universalism, 'communism', disinterestedness or organized scepticism, facts are the results of collective 'sexing-up' actions striving towards the establishment of scientific activities as decisive, economically vital activities with rewarding extensions into politically and economically sanctioned space and time. If this were not so, scientific activity would crumble into a pointless gesture 'limited to a point in time and space, myself, my dreams, my phantasies' (Latour, 1987: 108). Research is a strenuous construction of facts intended to attract, enrol and establish a prolific alliance between the researcher and the surrounding world - e.g. a prestigious international research project, a committee in a national/international research council and/or private enterprise, trade and industry.

Whether this alliance building succeeds or not, the premises under which the researcher has to operate are ultimately unpredictable; even if an economic or political alliance is established, the researcher has no guarantee that the results of the alliance won't be transformed into something unintended: 'The fate of facts and machines is in later users' hands; their qualities are thus a consequence, not a cause, of a collective action' (Latour, 1987: 259). The researcher is, in other words, dependent on the action of others:

You may have written the definitive paper proving that the earth is hollow and that the moon is made of green cheese but this paper will not become definitive if others do not take it up and use it as a matter of fact later on. You need them to make your paper a decisive one. If they laugh at you, if they are indifferent, if they shrug it off, that is the end of your paper. (Latour, 1987: 104)

This dependency makes the strategy of translation necessary; alliances must be involved and controlled at the same time and this is only made 
possible through translation. Latour here understands translation in a geometrical sense; the facts-through-alliance enterprise of science is a speech act where interests, resources and persons are moved or reshuffled from one location to another. 'Translating interests means at once offering new interpretations of these interests and channelling people in different directions' (Latour, 1987: 117). This reshuffling would be impossible if sexing-up strategies of exaggeration, hyping up or highlighting were not constantly involved. In order to translate and channel interests, persons and resources in required directions, specific aspects of the subject in question have to be infused with elements that make it noticeable. Sexingup strategies are thus core activities in translation processes, and if scientific activity presupposes translation in Latour's sense of the word, sexing-up strategies are as unavoidable in science as they are in politics whether we like it or not.

\section{THE WORLD IS NOT THE ACCOMPLICE OF OUR KNOWLEDGE}

Epistemologically, we cannot avoid translations or sexing-up interferences with the world. In his inaugural lecture at the Collège de France in 1970, 'The Order of Discourse', Michel Foucault presents some epistemological and methodological premises for what was supposed to be his future research projects. For an elaboration of critique as intervention involving strategies of sexing-up I find his outline of the so-called 'principle of specificity' particularly interesting:

We must not resolve discourse into a play of pre-existing significations; we must not imagine that the world turns towards us a legible face which we would have only to decipher; the world is not the accomplice of our knowledge; there is no pre-discursive providence which disposes the world in our favour. We must conceive discourse as a violence which we do to things, or in any case as a practice which we impose on them; and it is in this practice that the events of discourse find the principle of their regularity. (Foucault, 1981: 67)

The formulations here are perhaps a bit rough and pompous, and strictly speaking, the principle of specificity does not imply any 'new' philosophical thoughts about the relation between the world and our knowledge of it. Furthermore, the principle refers to an epistemological and methodological scheme that implies few indications of how to translate the principle into some kind of 'directions for use' in analysis and critique. Such 'directions for use' are not needed for an elaboration of critique as intervention, though. The important point to realize in relation to critique as intervention and the strategy of sexing-up is that any 
description of the world implies an interference with the world, since the world does not turn towards us a 'legible face' that we would only have to decipher. What this means is that 'translations' and sexing-up strategies must be replaced from the illegal and monstrous 'outside' and into the core of analysis as well as critique. This does not imply that analysis and critique should be turned into a non- or anti-scientific, magic enterprise devoid of clarity or rationality. On the contrary, critique as intervention has to employ precisely the criteria defining the object of critique, and the strategy of sexing-up is an essential part of this; an intervention to sex up a subject does not only mean to infuse it with elements that make it more noticeable but also to make the criteria defining it more noticeable.

\section{SEXING-UP A SEXUAL INDIFFERENCE - LUCE IRIGARAY}

I referred earlier to Luce Irigaray's conclusion that there is no 'simple manageable way to leap to the outside of phallogocentrism, nor any possible way to situate oneself there, that would result from the simple fact of being a woman' (Irigaray, 1985b: 162; emphasis in original). In Irigaray's early readings and rereadings of the western philosophical canon, a decisive connection is being established between phallogocentrism and sexual indifference. ${ }^{4}$ I read Irigaray's establishment of this connection as the result of a sexing-up reading strategy. The feminine in the works of Irigaray is neither positive nor negative because woman as The Other is not. Not because woman as The Other is not yet, as in not-yet-represented, but because she is unrepresentable. 'Woman' transcends and defies the possibilities of representation within the frameworks of phallogocentrism. Irigaray emphasizes this in her early works by outing phallogocentrism in a series of reopenings of the key concepts and myths of the western philosophical canon. The reopenings not only reveal an omission of the feminine - as in her reopening in Speculum of 'The myth of the cave' in Plato's Republic; the reopenings also reveal an omission of sexual difference. The domination of the philosophical logos stems 'in its greatest generality perhaps, from its power to eradicate the difference between the sexes in systems that are self-representative of a "masculine subject"' (Irigaray, 1985b: 74). With phallogocentrism sexual difference is not only made possible, it is replaced by a paradoxical and effective sexual indifference (Irigaray, 1985b: 72). This sexual indifference cannot be turned into a genuine sexual difference and the unrepresentability of woman cannot be abolished by answering questions of what sexual difference and woman really are. This 'What is ...' question is 'the metaphysical question - to which the feminine does not allow itself to submit' (Irigaray, 1985b: 122), because the answer to the question 'What is a woman?' can only situate 'woman' within phallogocentrism. 
Far from arguing in favour of essentialism - a strange allegation that seems to have been accorded with eternal life within some sections of feminist theory - Irigaray intervenes in the phallogocentrism of the western philosophical canon by sexing-up the sexual indifference at stake in the texts she works through. If 'woman' defies the possibilities of representation within phallogocentrism and if there is no way to situate 'woman' outside phallogocentrism that would result from the simple fact of being a woman she has to be sexed up as a product of sexual indifference, not as the hidden source of sexual indifference. The critical effects of Irigaray's interventions are not only that the criteria defining the philosophical subject have been made noticeable, but that they imply a possibility for feminist analysis and critique to move away from questions about woman as the subject or object within or outside phallogocentrism towards attempts at clarifications of the criteria defining and reproducing phallogocentrism. Thus it might become more noticeable that sexual discrimination not necessarily has anything to do with sexual indifference, but perhaps sooner should be understood as a question of phallogocentric sexual difference.

Against the power of phallogocentrism to reduce and wipe out the other in the Same, the strategy of sexing-up lends itself to feminist analysis and critique. Not just as a reading strategy, to be used in interventions in philosophical texts, but also as a strategy in empirical research. An important methodological premise for this assertion is that philosophical texts can be read as empirical data, and that the data of empirical research can be read as texts. Concerning the benefit of employing a sexing-up reading strategy in empirical research this is an implication of the productivity of problem representations.

\section{PRODUCTIVE PROBLEM REPRESENTATIONS}

I employ the concept 'problem representation' following Carol Bacchi (1999), who argues that political and social problems do not exist in themselves, but are established through interpretations, descriptions and negotiations of meaning. Bacchi bases her argument on efforts to integrate discourse analytic perspectives into policy studies, and she calls her approach 'What's the problem represented to be?' - formulated as a question replacing the perhaps more obvious one: 'What's the problem?' According to Bacchi:

... it makes no sense to consider the 'objects' or targets of policy as existing independently of the way they are spoken about or represented, either in political debate or in policy proposals. Any description of an issue or a 'problem' is an interpretation, and interpretations involve judgement and choices. Crucially, we also need to realize that interpretations are 
interventions since they have programmatic outcomes; that is, the interpretation offered will line up with particular policy recommendations. . . . More directly, policy proposals of necessity contain interpretations and hence representations of 'problems'. Therefore, we need to shift our analysis from policies as attempted 'solutions' to 'problems', to policies as constituting competing interpretations or representations of political issues. (Bacchi, 1999: 1-2)

I think that a significant implication of Bacchi's approach concerns the emphasis on the productivity of problem representations; 'policy proposals have inbuilt problem representations. That is, whatever is proposed creates in its formulation the shape of the problem addressed' (Bacchi, 1999: 66). Taking Bacchi a bit further, what this means is not only that different ideology-conditioned problem representations result in different solutions - that would be a rather trivializing merge of Marxist with Foucauldian epistemology; it also means that specific solutions actually presuppose specific problem representations. In order to attain specific critical effects or non-equal positionings in attempts at building accounts of the world that can be 'partially shared and friendly to earth-wide projects of finite freedom, adequate material abundance, modest meaning in suffering, and limited happiness' (Haraway, 1997: 187), special awareness has to be paid to the productivity of problem representations. The positive challenge for feminist critical intervention in science and politics following this argument is that it opens up possibilities of negotiations and renegotiations of problem representations, with a view to the effects, and not the standpoint or point of departure for the intervention. If specific solutions presuppose specific problem representations it is actually possible to obtain specific critical effects of an intervention. This is crucial for feminist analysis and critique. Furthermore, an awareness of and an ability to take into account the productivity of problem representations imply a recognition of translations or sexing-up strategies as part of the negotiations and renegotiations of the problem representations in question. If problems do not exist in themselves - i.e. are not recognized as problems - they have to be made so to speak, and they have to be made through reinterpretations, descriptions and renegotiations of meaning. This problem-making process involves translations and sexing-up strategies insofar as to sex up a subject is not only to infuse it with elements that make it more noticeable, but also to make the criteria defining it more noticeable and open to negotiations and renegotiations of meaning. As a conclusion to this article, I argue that an awareness of the productivity of problem representations can lead to an effective sexingup of a subject, that would otherwise find itself devoid of any problem status. The subject I have in mind is the question of gender equality in academia. 


\section{SEXING-UP A PROBLEM}

I think that the question of gender equality in academia is a good illustration of how important it is to reflect upon 'the representations offered by those who describe something as a problem and by those who deny an issue problem status' (Bacchi, 1999: 4), because it shows how different productive problem representations limit the range of possible solutions.

According to the Norwegian Council for Higher Education's committee Women in Science ${ }^{5}$ only 13 percent of the full-time professors in Norway are women. In the Nordic countries, Finland has the highest number of female professors, with approximately 18 percent, and Denmark the lowest number, with approximately 10 percent. Does this mean that we are talking about a problem of gender barriers in academia? I would say no. Gender barriers in academia are not a problem, or at least not a valid problem. This may sound a bit strange: am I suggesting that a discriminating mechanism making women's scientific contribution invisible in academia and unattractive as a labour force, favouring men and projects affirming masculine representations of our world, does not exist or is an acceptable element of academia? No.

What I have found by analysing discourses of gender and science in academia, based on interviews with employees and students at a Danish university, is that gender barriers simply do not make sense as a problem within the frameworks of academia. Solutions to this (meaningless) problem correspondingly do not make any sense as long as these solutions are based on discriminating tools as for instance quotas and earmarking. Discrimination based on 'blind' scientific judgements concerning quality, and the guarantee of basic equal opportunities, are the indisputable ideals of academia, not discrimination based on gender and an unequal distribution of opportunities. I am not basing this argument on what my informants 'told $\mathrm{me}^{\prime}$. I am basing my argument on an analysis of the problem representations that were negotiated, renegotiated and established in the interview texts.

What this analysis has led me to conclude is that gender barriers are not a valid problem in academia: gender barriers do not in themselves make sense as a problem - they have to be made a problem. This can be done in many ways. What these different ways have in common is that translations and sexing-up strategies must be involved. To make gender barriers into a problem could mean sexing-up the problem by 'revealing' different dubious and hidden agendas, secret networks and unfair mechanisms, or pointing to the fact that highly educated women have the most children, and that many women simply have priorities in life beyond scientific activity. This would make the subject noticeable, but the question is whether these problem representations imply solutions that could make sense, in a context where they were supposed to have critical 
effects. If to sex up a subject is not only to infuse it with elements that make it more noticeable, but also to make the criteria defining it more noticeable - and thus open to negotiations and renegotiations of meaning - then it seems insufficient to continue to insist on the existence of gender barriers. As if the world actually is 'an accomplice in our knowledge'.

It also seems insufficient to try to track down a secret, misogynist headquarters of male academic generals, who constantly attempt to keep academia a culture of men. If reality is established in processes of power exercised with points of departure in interplays between various noninnocent positions, no headquarters can be found. This does not imply that more or less hidden agendas do not exist or that gender barriers are the sad results of speculations of paranoid feminists unable to establish successful careers for themselves. The point I am trying to make is rather that the ways academia and the problems of gender barriers and inequality in academia are presented may be part of the problem of gender barriers and inequality, because we are dealing with problems that do not necessarily make sense as problems. If the sexing-up of gender barriers as a problem is also an intervention with critical effects, I think that what is needed are problem representations that construct, describe, combine and deconstruct intersections of categories that normally would resist intersection with a view to the effect of the intervention.

One way to make gender barriers in academia a problem, is to sex up the academic subject through a deneutralization of academia, where the academic subject becomes situated in intersections that make him or her noticeable as a non-neutral agent (Søndergaard, 2003). Another way is to sex up science itself, as a sexing-up enterprise, involving what Latour refers to as translations: where interests, resources and persons are moved or reshuffled from one location to another. In such a context, the construction and dismantling of barriers - also gender barriers - would be signs of normality; they would be considered parts of an enterprise where gender equality is never a matter of course, but a subject that has to be the critical effect of constant interventions.

Since the world does not show us a 'legible face which we would have only to decipher' no solutions to problems can be said to be reasonable because they rely on more or less correct descriptions of the real world. Solutions to specific problems are reasonable because they rely on problem representations that put specific limits on our knowledge of a specifically 'sexed-up' world.

\section{NOTES}

1. The question of gender equality in academia was the subject of my $\mathrm{PhD}$ dissertation, "“But it hasn't got anything to do with gender": Gender, Gender 
Barriers and Academia - Constructions of an Invalid Problem' (Egeland, 2000). The notion of feminist critique as intervention is a subject of my present postdoctoral project 'What Is Feminism?' (Egeland, 2003, 2004).

2. The climax of the battle of feminism in the 1990s was reached in the collection Feminist Contentions (Benhabib et al., 1995).

3. Source: BBC News Online.

4. I am here in particular referring to her works Speculum (Irigaray, 1985a) and This Sex Which Is Not One (Irigaray, 1985b).

5. See: www.uhr.no

\section{REFERENCES}

Bacchi, Carol L. (1999) Women, Policy and Politics: The Construction of Policy Problems. London, Thousand Oaks, CA and New Dehli: Sage.

Benhabib, S., J. Butler, D. Cornell and N. Fraser, eds (1995) Feminist Contentions: A Philosophical Exchange. London and New York: Routledge.

Braidotti, Rosi (2002) Metamorphoses: Towards a Materialist Theory of Becoming. Cambridge: Polity Press.

Egeland, Cathrine (2000) "“Men det har ikke noget med kønnet at gøre." Køn, kønsbarrierer og akademia - konstruktioner af et ugyldigt problem' ['But It Hasn't Got Anything to Do with Gender': Gender, Gender Barriers and Academia - Constructions of an Invalid Problem], dissertation, University of Southern Denmark.

Egeland, Cathrine (2003) 'Kraften i det underforståtte - noen overveielser om feministisk forskning' [The Power of the Implied: Some Considerations on Feminist Research], Kvinneforskning 4: 5-15.

Egeland, Cathrine (2004) 'Interventions in a Cat's Cradle', NORA: Nordic Journal of Women's Studies 1(12): 83-92.

Foucault, Michel (1981) 'The Order of Discourse', pp. 48-78 in Robert Young (ed.) Untying the Text: A Post-Structuralist Reader. Boston, MA, London and Henley: Routledge and Kegan Paul. (Orig. pub. 1971.)

Haraway, Donna J. (1997) Modest_Witness@Second_Millennium. Femaleman@ Meets Oncomouse ${ }^{\mathrm{TM}}$ : Feminism and Technoscience. New York: Routledge.

Irigaray, Luce (1985a) Speculum of the Other Woman. New York: Cornell University Press.

Irigaray, Luce (1985b) This Sex Which Is Not One. New York: Cornell University Press.

Kavka, Misha (2001) 'Introduction', pp. xi-xxvi in E. Bronfen and M. Kavka (eds) Feminist Consequences: Theory for the New Century. New York: Columbia University Press.

Latour, Bruno (1987) Science in Action. Cambridge, MA: Harvard University Press.

Merton, Robert K. (1996) On Social Structure and Science, ed. P. Sztompka. Chicago, IL: University of Chicago Press. (Orig. pub. 1942.)

Schaanning, Espen (2000) Fortiden i våre hender. Foucault som vitenshåndtør [The Past in our Hands: Foucault as Manager of Knowledge]. Oslo: Unipub forlag.

Søndergaard, Dorte Marie (2003) 'Orientering og desorientering i Akademia' [Orientation and Disorientation in Academia], pp. 61-99 in Lis Højgaard and Dorte Marie Søndergaard (eds) Akademisk tilblivelse. Akademia og dens kønnede befolkning [Academic Becoming: Academia and its Gendered Population]. Copenhagen: Akademisk Forlag. 
Utaker, Arild (1984) Kunnskapens makt. En innledning til Michel Foucault [The Power of Knowledge. An Introduction to Michel Foucault]. Bergen: University of Bergen.

Cathrine Egeland is a postdoctorate fellow at the Centre for Women's and Gender Research, University of Bergen. She received her PhD degree on the dissertation "But It Hasn't Got Anything to Do with Gender": Gender, Gender Barriers and Academia - Constructions of an Invalid Problem' from the University of Southern Denmark in 2001. She has published on feminist philosophy, gender equality in academia and feminist theory of science. Address: Centre for Women's and Gender Research, University of Bergen, P.b. 7800, Allégaten 34, N - 5020 Bergen, Norway. [email: cathrine.egeland@skok.uib.no] 